\title{
Induction of a bystander effect after therapeutic ultrasound exposure in human melanoma: In-vitro assay
}

\section{Rezaei ${ }^{1}$, R. Kamran Samani ${ }^{1}$, M. Kazemi² ${ }^{2}$ A. Shanei ${ }^{*}$, S.H. Hejazi 3}

\author{
${ }^{1}$ Department of Medical Physics, School of Medicine, Isfahan University of Medical Sciences, Isfahan, Iran \\ ${ }^{2}$ Department of Genetics and Molecular Biology, School of Medicine, Isfahan University of Medical Sciences, \\ Isfahan, Iran \\ ${ }^{3}$ Department of Parasitology and Mycology, School of Medicine, Isfahan University of Medical Sciences, Isfahan, \\ Iran
}

\section{- Original article}

\section{*Corresponding authors:}

Ahmad Shanei, $P h D$.,

E-mail: shanei@med.mui.ac.ir

Revised: February 2020

Accepted: February2020

Int. J. Radiat. Res., January 2021; 19(1): 183-189

DOI: $10.29252 /$ ijrr.19.1.183

\section{ABSTRACT}

Background: The induction of bystander effect via ionizing radiation has been well proven. However, few studies have investigated the bystander effect following non-ionizing radiation, such as ultrasound waves. Here, the bystander effect after different sonication times on human melanoma cell line (A375), is evaluated by assessing cell viability and apoptosis. Materials and Methods: The cells were divided into two main target and bystander groups. Target cells were exposed to $1 \mathrm{MHz}$ ultrasound at $2 \mathrm{~W} / \mathrm{cm}^{2}$ intensity for 1,2 , 5 and $10 \mathrm{~min}$ with an ultrasound unit. Then, bystander cells received the cell culture medium of target cells. MTT and flow cytometry assays were used to determine the cell' viability at different times after exposure and medium transfer, as well as the detection of apoptosis. Results: The cell' viability in ultrasound-exposed target cells was less than $75 \%$ for 24 and $48 \mathrm{~h}$ incubation. Furthermore, bystander cell' viability was not significantly different from the control group 1 and $12 \mathrm{~h}$ after receiving the culture medium of target cells. However, bystander cells viability 24 and $48 \mathrm{~h}$ after target cells medium transfer was significantly decreased $(\mathrm{P}=0.01)$. The apoptosis rate of bystander cells, 24 and $48 \mathrm{~h}$ after receiving the cell culture medium of target cells, showed significant differences from the control group. Conclusion: This research results revealed that the ultrasound waves could induce a biological effect in A375 bystander cells which were not directly exposed to direct ultrasound.

Keywords: Bystander effect, ultrasound waves, MTT assay, apoptosis assay, A375 cell line.

\section{INTRODUCTION}

It is well established that radiation can induce cellular responses in non-irradiated cells which are termed radiation-induced bystander effect (RIBE) (1). This phenomenon leads to radiation induced-injuries in non-irradiated bystander cells. As reported, non-irradiated cells show a variety of biological responses, including reduced viability fraction (2), chromosomal instability (3), DNA double strand-breaks, apoptosis (4), and changed dynamic balance between proliferation (5).

RIBEs, after ionizing radiation, have been well documented. However, a few studies have investigated the bystander effects as a result of other environmental factors, including some electromagnetic waves as ultraviolet light (6-10) and radio frequency waves (11) and also after chemotherapy (12) and photodynamic therapy, 
treatment modalities (13-15). Bystander mechanisms have not fully been understood yet. However, it has been found that some signaling factors, such as Reactive Oxygen Species (ROS), NO (15), and $\mathrm{OH}$ radicals $(17,18)$, released from irradiated cells have medium-mediated bystander effect.

Ultrasound is one of the non-invasive modalities for the treatment of some cancers (19), which is defined as mechanical vibration produced via sound waves with a frequency of more than $20 \mathrm{kHz}$ [20]. It has been reported that the effective therapeutic frequency of ultrasound is in the range of 0.8 to $3 \mathrm{MHz}{ }^{(21,22)}$.Ultrasound waves by different thermal, mechanical, and micro-bubbles cavitation can play vital roles in cancer treatments (23-25). Physically, the ultrasound waves could may increase the temperature of the cell microenvironment by the generation of thermal energy ${ }^{(22,26,27)}$ and also bubble (28). Ultrasound, with a frequency of 1 $\mathrm{MHz}$ and 0.5 to $3.0 \mathrm{~W} / \mathrm{cm}^{2}$ intensities (low-intensity ultrasound), can produce inertial cavitation inside the tumor volume (19). Mechanical shock waves induce biological effect as a result of the collapse in microbubbles. In other words, when the bubbles burst by localized spots with high temperature and pressure, they cause free radicals formation and apoptotic initiators, that inhibit cancer cell growth (19). Hydroxyl radicals $(\cdot \mathrm{OH})$, hydrogen peroxide $\left(\mathrm{H}_{2} \mathrm{O}_{2}\right)$, and hydroperoxyl radicals (HOO) are some species of produced free radicals by ultrasound waves, which induce chemical changes (27). Apoptosis is the endogenous programmed cell death that allows the maintenance of cellular homeostasis (29). Based on the author's knowledge, in most biological studies, apoptosis induced by ultrasound even at low intensities in target cells has been proven (30), and hence there is no information to describe the induced apoptosis in bystander cells.

To the best of the author's knowledge, there is no study on the bystander effect following ultrasound therapy. Therefore, considering the therapeutic effects of low-intensity ultrasound and also according to the role of the bystander effect on cancer treatment, in this work the bystander effect following ultrasound exposure on the A375 cell lines are investigated. To evaluate the effects of target cell following ultrasound exposure on the bystander cells, the cell viability and apoptosis are evaluated using MTT assay and flow cytometry, respectively.

\section{MATERIALS AND METHODS}

All procedures performed in this study involving cellular experiments (in vitro), were under the ethical standards of the institutional and/or national research committee and the 1964 Helsinki declaration, as well as its later amendments or comparable ethical standards.

\section{Cell line and culture conditions}

A375, as a cancer cell line of human melanoma, was purchased from Pasteur Institute in Tehran, Iran. The cells were cultured in Roswell Park Memorial Institute1640 medium (RPMI 1640, Gibco, Germany) containing 10\% Fetal Bovine Serum (FBS, Gibco, Germany), streptomycin (1 $\mathrm{mg} / \mathrm{ml}$, Biosera, France), and penicillin (1000 units/ml, Biosera, France); then, they were incubated at $37{ }^{\circ} \mathrm{C}$ in a humidified atmosphere with $5 \% \quad \mathrm{CO}_{2}$. The cells were cultured in T25 flasks and then transferred to 12 and 96 wells plates for examinations.

\section{Ultrasound generator system and exposure set up}

In this study, ultrasound irradiation was provided by a therapeutic ultrasound unit (215A; a coproduct of Novin Medical Engineering Co., Tehran, Iran; and EMS Co., Reading, Berkshire, England) in continuous mode at a frequency of $1 \mathrm{MHz}$ with an intensity of $2 \mathrm{~W} / \mathrm{cm}^{2}$ (I $\left.\mathrm{I}_{\text {SATA }}\right)$. Acoustic calibration for the frequency and intensity of the device was carried out in degassed water in a tank, using a calibrated PVDF-type hydrophone (PA124, Precision Acoustics Ltd., Dorchester, Dorset, UK) on the transducer axis to record the ultrasonic signals. The temperature rise during the exposure was checked by a thermometer, which was inserted in the water tank, to keep the temperature of the cells below the hyperthermia 
level.

For ultrasound exposure, the transducer was fixed in a hole at the bottom of the water tank; then, the 12-well plate was placed in the near field of the transducer. The floor of the plate was in direct contact with the water in the water tank.

\section{Cell viability assay}

The MTT test was used to determine the percentage of cell viability. After cell treatment, the cell culture media was removed, and the culture medium was replaced with a mixture of $100 \mu \mathrm{l} \mathrm{RPMI}$ and $10 \mu \mathrm{l}$ of MTT solution $(5 \mathrm{mg} /$ $\mathrm{mL}$ ) (Sigma, St. Louis, MO, USA) for each well (in a 96-well plate) then incubated for 4 hours. Then, the MTT solution was removed entirely, and $50 \mu \mathrm{l}$ of Dimethyl Sulfoxide (DMSO, Sigma, USA) was added and incubated for $15 \mathrm{~min}$. All experiments were repeated for three independent times. Finally, optical densities (OD) were measured at $570 \mathrm{~nm}$ by a spectrophotometer (Stat Fax 2100, USA) .Cell viability values were determined using equation (1):

Cell viability $=\frac{\mathrm{OD}_{\text {treated }}}{\mathrm{OD}_{\text {control }}} \times 100$

\section{Ultrasound exposure of target cells}

To determine the effect of ultrasound waves at different times on target A375 cells, the cells were cultured in 12 -well plates $\left(5 \times 10^{4}\right.$ cell/ well). After the cells adhered to the plate, the cell culture was replaced with fresh medium containing $10 \%$ FBS and exposed to $1 \mathrm{MHz}$ ultrasound at $2 \mathrm{~W} / \mathrm{cm}^{2}$ intensity for $1,2,5$, and 10 min with ultrasound unit. Then, the viability of target cells was measured 1, 12, 24, and $48 \mathrm{~h}$ after ultrasound exposed with the MTT test.

\section{Induced bystander effect using medium transfer}

In this study, the medium transfer method was used to induce a bystander effect in A375 non-irradiated cells. One hour following ultrasound exposure, cell culture of ultrasound exposed cells was collected and passed through a $0.22 \mu \mathrm{m}$ filter (Orange Scientific, Belgium) to remove cells plus cell debris and transfer to the specified bystander cell plates. The bystander cells were incubated for $1,12,24$, and 48 hours after receiving the target cell culture medium. Then, MTT assay and apoptosis tests were performed .

\section{Measurement of bystander cells apoptosis}

Apoptosis was detected by the eBioscience ${ }^{\mathrm{TM}}$ Annexin V Apoptosis Detection Kit II (Invitrogen, USA). After bystander cell treatment, the culture medium of each well containing floating cells was collected, and adherent cells were detached by trypsin. Afterward, both floating and adherent cells were poured into a flow cytometry tube, washed twice with PBS (100x), and centrifuged at $300 \mathrm{~g}$ for 10 minutes at $15^{\circ} \mathrm{C}$. Then, the cell was incubated in $100 \mu$ l of binding buffer $(1 \mathrm{x})$ with $2 \mu \mathrm{l}$ Annexin-V and $2 \mu \mathrm{l}$ propidium iodide (PI) for $15 \mathrm{~min}$ in the dark at room temperature. Next, 10,000 cells, for each sample were recorded on a Flow Cytometer (BD FACS Calibur, USA), and fluorescence-activated cell sorting (FACS) data were analyzed using open-source software.

\section{Data analysis}

Each experiment was carried out in triplicate. The viability data were noted as mean \pm standard deviation. The data distribution was normal according to the Kolmogorov-Smirnov normality test, and the statistical comparison of groups was done by one-way analysis of variance (ANOVA) at $\mathrm{P}<0.05$. Each experiment was performed in triplicate.

\section{RESULTS}

The data obtained in the first part of the study permit comparing the viability of A375 cells in the target groups (ultrasound exposed cells) $1,2,5$, and $10 \mathrm{~min}$ with respect to the control cells following incubation times of 1,12 , 24 , and $48 \mathrm{~h}$ (figure 1).

The graphs indicate the dependence of the range value of relative cell viability on the incubation and ultrasound exposure time. The 
graph of 1 min shows large variability in the viability values for each exposure time. The results of the $12 \mathrm{~h}$ experiment show a statistical difference for 5 and 10 min ultrasound exposure time; the lowest viability value is found for 10 min from all exposure times (90\%).

The graph of the $24 \mathrm{~h}$ illustrates a decrease in viability of ultrasound exposed groups at $1,2,5$, and $10 \mathrm{~min}$. The experimental results of the $48 \mathrm{~h}$ show the statistical difference $(P<0.001)$ between ultrasound exposed groups at 1, 2, 5, and 10 min with the control group (table 1), as the $24 \mathrm{~h}$ group. The lowest viability value is found for $10 \mathrm{~min}$ of ultrasound exposure time, which reached values of less than $73 \%$ of the control group. The group $5 \mathrm{~min}$ exposure time is on the viability level of $85 \%$ value of the control. The group $1 \mathrm{~min}$ ultrasound exposure time reaches the higher value of viability in comparison with the other groups, about $97 \%$ value of the control group.

According to figure 2, there are no differences in the viability of bystander groups with 1 and $12 \mathrm{~h}$ incubation for all exposure times. The graphs exhibit similar levels of bystander cell viability after 1 and $12 \mathrm{~h}$ incubation for all exposure time to the control group ( $\mathrm{P}>\mathrm{0.05}$ ). However, the viability of bystander groups after 24 and $48 \mathrm{~h}$ incubation times following $10 \mathrm{~min}$ ultrasound exposure shows the statistically significant difference with the control group $(\mathrm{P}<0.001)$, in these groups the viability level of $90 \%$ value of the control. In these groups, they are more apoptotic than the control group.

Moreover, the dual staining method with Annexin V-FITC and PI was utilized to assess apoptosis in bystander cells. Figure 3 illustrates the fraction of A375 bystander cells undergoing apoptosis. The sum of the lower right quadrant (early apoptosis) and upper right quadrant (late apoptosis) represents the total apoptosis rate. In this study, apoptosis induction in bystander cells after $24 \mathrm{~h}$ (10.94\%) and 48h (13.25\%) incubation with target cell culture media exposed with 10 min ultrasound is evaluated. A slight increase in the apoptosis of bystander cells after $24 \mathrm{~h}$ incubation compared to the control group is observed $(\mathrm{P}=0.01)$, and the significant difference occurs at $48 \mathrm{~h}$ incubation after $10 \mathrm{~min}$ ultrasound exposure. Therefore, 10 min ultrasound exposure time with $2 \mathrm{~W} / \mathrm{cm}^{2}$ intensity induces apoptosis in bystander cells compared to control cells.

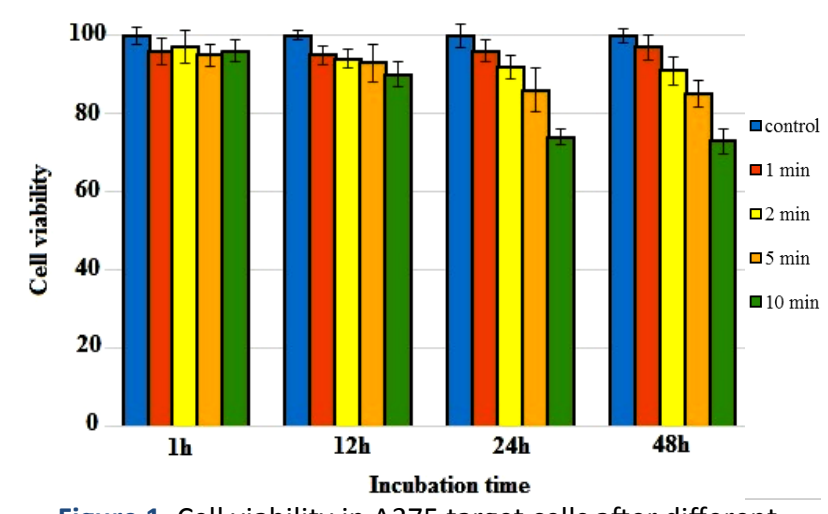

Figure 1. Cell viability in A375 target cells after different ultrasound exposure $(1,2,5$, and $10 \mathrm{~min})$ and incubation times $(1,12,24$, and $48 \mathrm{~h})$.

Table 1. Significance of differences in viability values in target and bystander groups. Target cells are exposed to ultrasound of intensity $2 \mathrm{~W} / \mathrm{cm} 2$ for $1,2,5$, and 10 minutes. Then the medium transfer technique is performed. Cell viability is evaluated after $1,12,24$, and $48 \mathrm{~h}$ incubation times. no significance, $\boldsymbol{\Delta}$ statistical significance at $\mathrm{P}<0.05$.

\begin{tabular}{|c|c|c|c|}
\hline \multicolumn{2}{|c|}{ Target } & \multicolumn{2}{|c|}{ Bystander } \\
\hline & Control & & Control \\
\hline $1 \mathrm{~h}$ & & $1 \mathrm{~h}$ & \\
\hline Con & ---- & Con & ---- \\
\hline $1 \mathrm{~min}$ & & $1 \mathrm{~min}$ & \\
\hline $2 \min$ & & $2 \min$ & \\
\hline $5 \mathrm{~min}$ & & $5 \mathrm{~min}$ & \\
\hline $10 \min$ & & $10 \min$ & \\
\hline $12 \mathrm{~h}$ & & $12 \mathrm{~h}$ & \\
\hline Con & ---- & Con & $=-$ \\
\hline $1 \mathrm{~min}$ & & $1 \mathrm{~min}$ & \\
\hline $2 \min$ & & $2 \min$ & \\
\hline $5 \min (93 \%)$ & & $5 \mathrm{~min}$ & \\
\hline $10 \min (90 \%)$ & & $10 \min$ & \\
\hline $24 \mathrm{~h}$ & & $24 \mathrm{~h}$ & \\
\hline Con & ---- & Con & \\
\hline $1 \mathrm{~min}$ & & $1 \min$ & \\
\hline $2 \min (92 \%)$ & & $2 \min$ & \\
\hline $5 \min (86 \%)$ & & $5 \min$ & \\
\hline $10 \min (74 \%)$ & & $10 \min (89 \%)$ & \\
\hline $48 \mathrm{~h}$ & & $48 \mathrm{~h}$ & \\
\hline Con & --- & Con & ---- \\
\hline $1 \mathrm{~min}$ & & $1 \mathrm{~min}$ & \\
\hline $2 \min (91 \%)$ & $\Delta$ & $2 \min$ & \\
\hline $5 \min (85 \%)$ & 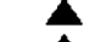 & $5 \mathrm{~min}$ & \\
\hline $10 \min (73 \%)$ & $\Delta$ & $10 \min (86 \%)$ & 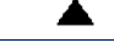 \\
\hline
\end{tabular}

Int. J. Radiat. Res., Vol. 19 No. 1, January 2021 


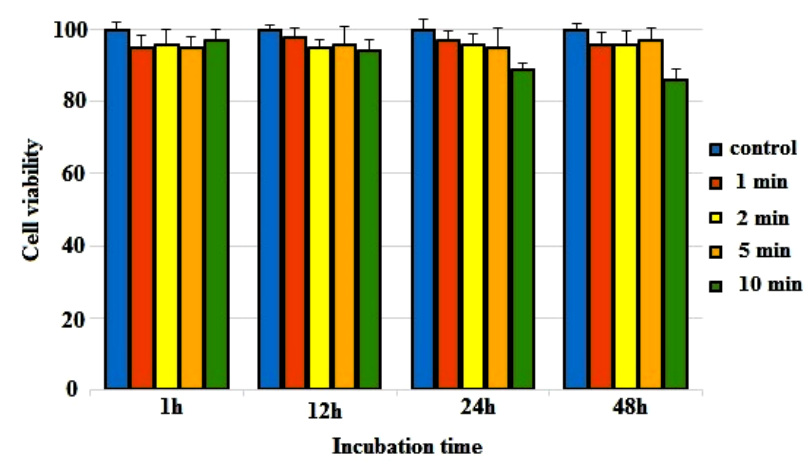

Figure 2. Cell viability in $A 375$ bystander cells after different ultrasound exposure $(1,2,5$, and $10 \mathrm{~min})$ and incubation times $(1,12,24$, and $48 \mathrm{~h})$.
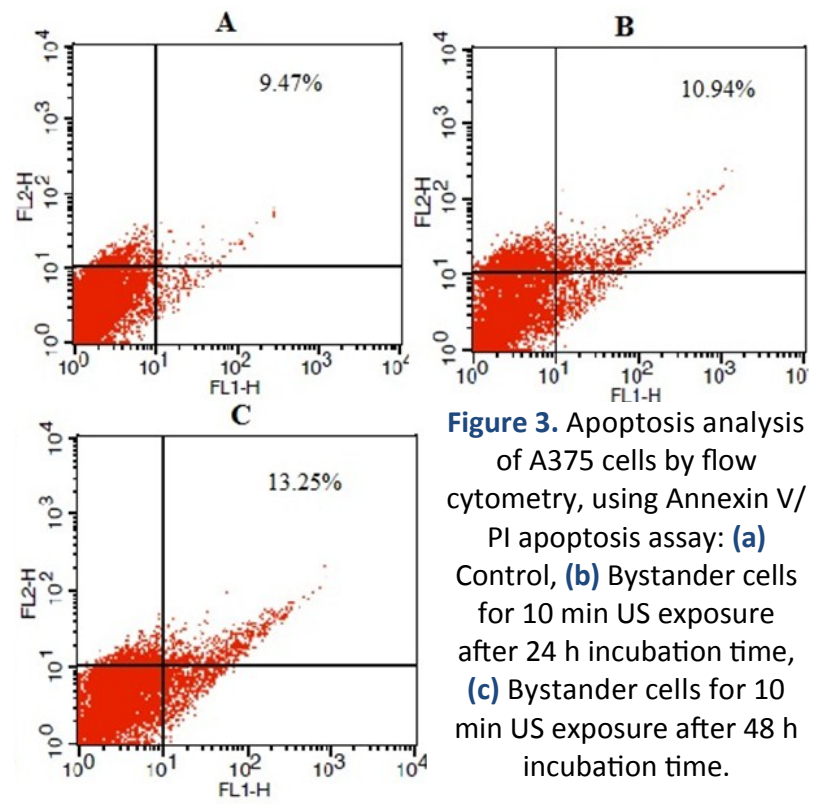

Figure 3. Apoptosis analysis of $A 375$ cells by flow cytometry, using Annexin V/ PI apoptosis assay: (a) Control, (b) Bystander cells for 10 min US exposure after $24 \mathrm{~h}$ incubation time, (c) Bystander cells for 10 min US exposure after $48 \mathrm{~h}$ incubation time.

\section{DISCUSSION}

Studies have shown that the therapeutic frequency of ultrasound can induce cell death. Under our conditions, cell death is detected by the MTT method in target and bystander cells. In the present paper, the MTT assay results of target cells indicate therapeutic ultrasound with $1 \mathrm{MHz}$ frequency, and $2 \mathrm{~W} / \mathrm{cm}^{2}$ intensity causes A375 cell death.

The cell death induced by ultrasound is predicted to be caused by acoustic cavitation. These findings are in agreement with the presented results based on which the percentage cell death of lung cancer of cell lines after ultrasound exposure has been revealed to

Int. J. Radiat. Res., Vol. 19 No. 1, January 2021 be $32 \%$ (31). Also, in other studies (31,32), cell death by ultrasound in target cells have been from $55 \%$ to $68 \%$. In another study, Wang et al. showed that, in $2 \mathrm{~W} / \mathrm{cm}^{2}$ ultrasound intensity, the acoustic cavitation becomes a dominant effect as a result of producing more $\bullet \mathrm{OH}$ free radical, which may cause cell death (33). Based on the results, the decline in cell death has been enhanced by the increased exposure time (figure 1).

Moreover, the cell death for $10 \mathrm{~min}$ ultrasound exposure is significantly higher than 1,2 , and $5 \mathrm{~min}$. In some studies with different cell lines, it is demonstrated that cell death of ultrasound exposed cells increases, and it is mainly dependent on time. Therefore, cell viability is reduced with increasing ultrasound exposure time ${ }^{(34,35) .}$

In this study, the cell viability of bystander groups at different irradiation and incubation times is evaluated. The cell viability of bystander groups illustrates a significant difference compared to the control group, when both ultrasound exposure and incubation times are increased.

The bystander cells after 24 and $48 \mathrm{~h}$ incubation with $10 \mathrm{~min}$ ultrasound exposed target cell media show significant cell death. However, this phenomenon does not occur in bystander cells after less than $10 \mathrm{~min}$ of ultrasound exposure time and also 1 and $12 \mathrm{~h}$ incubation times. Therefore, it seems that, increasing the exposure time is a vital factor to induce bystander effect. It is due to the high free radical production when ultrasound exposure time increases. Also, cell viability after 24 and 48 $\mathrm{h}$ incubation is not significantly different from each other. Therefore, 24 hours can be a suitable incubation time to induce the bystander effect in non-targeted cells.

Many studies have shown that ionizing radiation can induce cell death $(23 \pm 2 \%)$ in non-irradiated cells even after $30 \mathrm{~min}$ incubation bystander cells with target cell culture media (36). However, in this study, cell death is observed in the bystander group in $24 \mathrm{~h}$ after receiving the target group medium. These findings can be related to this fact that ionizing radiation has a destructive nature and different 
mechanisms to induce bystander effect compared with ultrasound waves.

It is evidently that the viable cells in bystander cells decrease after receiving the target culture medium. The mechanism of cell death induced by ultrasound in A375 bystander cells is evaluated by flow cytometry. The results indicate that the culture media of ultrasound exposed target cells after $10 \mathrm{~min}$ can induce apoptosis in the bystander cells after 24 and 48 $\mathrm{h}$ incubation (figure 3 ). The percentage of early apoptosis is increased $(\mathrm{P}<0.05)$ compared to the control cells, which have proved the apoptosis of cells to be induced in bystander cells by ultrasound indeed.

There was no information regarding the influence of ultrasound exposed target cells on bystander apoptosis rate. Whereas previous studies have shown increased apoptotic cells after ultrasound exposure in target cells (29), based on the author's our knowledge, apoptosis induction in bystander cells has not been investigated in other studies. However, further evaluations, such as analysis of protein expression changes and their functions that are crucial to detect the related metabolic process and assessment of the potential mechanism of ultrasound that may cause cell apoptosis in bystander cells, are needed.

In conclusion, recent evidence indicates that ultrasound has good prospects in the treatment of melanoma. In this study, the low intensity of ultrasound waves is utilized to more accurately evaluating them on A375 human melanoma cells, which are located outside the radiation field. According to the results of this study, the killing/destructive effect of ultrasound on A375 cells is exposure time-dependence. Also, ultrasound waves can create signals in the culture medium of directly exposed cells that may lead to apoptosis in bystander cells. Therefore, ultrasound waves can affect the cells outside the ultrasound exposure field, as a result of bystander effects.

\section{CONCLUSION}

In this research, the findings prove that the 188 killing effect of ultrasound on A375 cells is exposure time-dependence. Also, ultrasound waves can create signals in the culture medium of directly exposed cells that may lead to apoptosis in bystander cells. Therefore, ultrasound waves can affect the cells outside the ultrasound exposure field, as a result of bystander effects. In other words, the biological effects of ultrasound waves are not limited to the physical exposure field.

\section{ACKNOWLEDGEMENTS}

The authors would like to thank research deputy of Isfahan University of Medical Sciences for funding this work.

\section{Ethical statements:}

This article does not contain any studies on human or animal subjects performed by the any of the authors.

\section{Conflicts of interest: Declared none.}

\section{REFERENCES}

1. Marin A, Martín $M$, Linan $O$, Alvarenga $F$, Lopez $M$, Fernandez L, Buchser D, Cerezo L (2015) Bystander effects and radiotherapy. Rep Practical Onco \& Radiat, 20: 12-21.

2. Mitchell SA, Randers G, Brenner DJ, Hall EJ (2004) The Bystander Response in C3H 10T 1/2 Cells : The Influence of Cell-to-Cell Contact. Radiat Res, 401: 397-401.

3. Watson GE, Lorimore SA, Macdonald DA, Wright EG (2000) Advances in Brief Chromosomal Instability in Unirradiated Cells Induced in Vivo by a Bystander Effect of Ionizing Radiation 1. Cancer Res, 60: 5608-5611.

4. Mothersill CE, Moriarty MJ, Seymour CB (2004) Radiotherapy and the potential exploitation of bystander effects. Int J Radiat Oncol Biol Phys, 58: 575-579.

5. Marín A, Martín M, Li O, Alvarenga F, López M, Fernández L, Büchser D, Cerezo L (2014) Bystander effects and radiotherapy. Rep Pract Oncol Radiother, 20: 12-21.

6. Widel M (2012) Bystander effect induced by UV radiation; why should we be interested? Postepy Hig Med Dosw, (Online) 66: 828-837.

7. Dahle J, Kvam E, Stokke T (2005) Bystander effects in UVinduced genomic instability: antioxidants inhibit delayed mutagenesis induced by ultraviolet $A$ and $B$ radiation. $J$ Carcinog, 4: 11 .

Int. J. Radiat. Res., Vol. 19 No. 1, January 2021 
8. Banerjee G, Gupta N, Kapoor A, Raman G (2005) UV induced bystander signaling leading to apoptosis. Cancer Lett, 223: 275-284.

9. Dahle J, Kaalhus O, Stokke T, Kvam E (2005) Bystander effects may modulate ultraviolet $A$ and $B$ radiationinduced delayed mutagenesis. Radiat Res, 163: 289-295.

10. Dahle J and Kvam E (2003) Induction of delayed mutations and chromosomal instability in fibroblasts after UVA -, UVB-, and X-radiation. Cancer Res, 63: 1464-1469.

11. Calatayud MP, Asin L, Tres A, Goya GF, Ibarra MR (2016) Cell Bystander Effect Induced by Rediofrequency Electromagnetic Fields and Magnetic Nanoparticles. Curr Nanosci, 12: 372-377.

12. Alexandre J, Hu Y, Lu W, Pelicano H, Huang P (2007) Novel action of paclitaxel against cancer cells: bystander effect mediated by reactive oxygen species. Cancer Res, 67: 3512-3517.

13. Chakraborty A, Held KD, Prise KM, Liber HL, Redmond RW (2009) Bystander effects induced by diffusing mediators after photodynamic stress. Radiat Res, 172: 74-81.

14. Dabrowska A, Gos M, Janik P (2005) Bystander effect induced by photodynamically or heat-injured ovarian carcinoma cells (OVP10) in-vitro. Med Sci Monit, 11: BR316-24.

15. Dahle J, Kaalhus O, Moan J, Steen HB (1997) Cooperative effects of photodynamic treatment of cells in microcolonies. Proc Natl Acad Sci, 94: 1773-1778. USA.

16. Azzam El, de Toledo SM, Little JB (2003) Oxidative metabolism, gap junctions and the ionizing radiation-induced bystander effect. Oncogene, 22: 7050-7057.

17. Barati AH , Mokhtari-Dizaji M, Mozdarani H, Bathaei SZ, Hassan ZM (2006) Free hydroxyl radical dosimetry by using $1 \mathrm{MHz}$ low level ultrasound waves TT . Int J Radiat Res, 3: 163-169.

18. Sazgarnia A and Shanei A (2012) Evaluation of acoustic cavitation in terephthalic acid solutions containing gold nanoparticles by the spectrofluorometry method. Int J Photoenergy, 42: 376-381.

19. Sengupta S and Balla VK (2018) A review on the use of magnetic fields and ultrasound for non-invasive cancer treatment. J Adv Res, 14: 97-111.

20. Wood AKW and Sehgal CM (2015) A review of lowintensity ultrasound for cancer therapy. Ultrasound Med Biol, 41: 905-928.

21. Nyborg J.W. W. L. M. (2006) Emerging therapeutic ultrasound. World Scientific Publishing c2006. Ltd, Singapore.

22. Malaysiana S, Keamatan U, Aruhan R, Sel J, Payudara K (2017) Low intensity ultrasound induced apoptosis in MCF -7 breast cance. Cell Lines, 46: 575-581.

23. Beik J, Abed Z, Ghoreishi FS, Hosseini-Nami S, Mehrzadi S, Shakeri-Zadeh A, Kamrava SK (2016) Nanotechnology in hyperthermia cancer therapy: From fundamental principles to advanced applications. J Control Release, 235: 205 -221 .
24. Shanei A and Akbari-Zadeh $H$ (2019) Investigating the Sonodynamic-Radiosensitivity Effect of Gold Nanoparticles on HeLa Cervical Cancer Cells. J Korean Med Sci, 34: e243.

25. Shanei A, Akbari-Zadeh $H$, Fakhimikabir $H$, Attaran $N$ (2019) The role of gold nanoparticles in sonosensitization of human cervical carcinoma cell line under ultrasound irradiation: an in-vitro study. Journal of Nano Research, 59: 1-14.

26. Hasanzadeh ., Mokhtari-Dizaji M, Bathaie SZ, Hassan ZM (2011) Effect of local dual frequency sonication on drug distribution from polymeric nanomicelles. Ultrason Sonochem, 18: 1165-1171.

27. Ebrahiminia A, Mokhtari-dizaji M, Toliyat T (2013) Ultrasonics Sonochemistry Correlation between iodide dosimetry and terephthalic acid dosimetry to evaluate the reactive radical production due to the acoustic cavitation activity. Ultrason Sonochemistry, 20: 366-372.

28. Ninomiya K, Yamashita T, Kawabata S, Shimizu N (2014) Targeted and ultrasound-triggered drug delivery using liposomes co-modified with cancer cell-targeting aptamers and a thermosensitive polymer. Ultrason Sonochem, 21: 1482-1488.

29. Watanabe A, Kawai K, SatoT, Nishimura H, Kawashima $\mathrm{N}$,Takeuchi S (2004) Apoptosis induction in cancer cells by ultrasound exposure. Jpn J Appl Phys, 43: 3245-9.

30. Guo S, Sun X, Cheng J, Xu H, Dan J, Shen J, Zhou Q, Zhang Y, Meng L, Cao W, et al. (2013) Apoptosis of THP-1 macrophages induced by protoporphyrin IX-mediated sonodynamic therapy. Int J Nanomedicine, 8: 2239-2246.

31. Wan GY, Liu Y, Chen BW, Liu YY, Wang YS, Zhang N (2016) Recent advances of sonodynamic therapy in cancer treatment. Cancer Biol Med 13: 325.

32. Canavese G, Ancona A, Racca L, Canta M, Dumontel B, Barbaresco F, Limongi T, Cauda V (2018) Nanoparticleassisted ultrasound: A special focus on sonodynamic therapy against cancer. Chem Eng J, 340: 155-172.

33. Wang P, Li Y, Wang X, Guo L, Su X, Liu Q (2012) Membrane damage effect of continuous wave ultrasound on K562 human leukemia cells. J Ultrasound Med, 31: 19771986.

34. Yamamoto S, Ono M, Yuba E (2017) In-vitro Sonodynamic therapeutic effect of polyion complex micelles incorporating titanium dioxide nanoparticles. Nanomaterials, 7: 268.

35. Physiology C (2018) Apoptosis of THP-1 macrophages induced by pseudohypericin-mediated sonodynamic therapy through the mitochondria-caspase pathway. Cell Physiol Biochem, 38: 545-557.

36. Han W, Wu L, Hu B, Zhang L, Chen S, Bao L, Zhao Y, Xu A (2007) The early and initiation processes of radiationinduced bystander effects involved in the induction of DNA double strand breaks in non-irradiated cultures. $\mathrm{Br} J$ Radiol, 80: 7-12. 
